Сиротенко А. М., к.т.н. (ORCID: 0000-0002-0266-5706)

Національний університет оборони України імені Івана Черняховського

\title{
Рекомендації щодо інтеграції зусиль військових і невійськових суб'єктів сектору безпеки і оборони для нейтралізації загроз воснного характеру
}

Резюме. У статті наведено рекомендації щодо комплексного використання військових (силових) i невійськових (несилових) суб'єктів сектору безпеки і оборони України для протидії загрозам воєнного характеру. Рекомендації розроблено з урахуванням основних принципів, за якими має відбуватися інтегрування військових і невійськових суб'єктів для нейтралізації загроз воєнного характеру та методу адаптивного управління інтегрованим потенціалом протидії виявленим (прогнозованим) загрозам.

Ключові слова: воєнна безпека; військові та невійськові суб'єкти; інтегрований потенціал протидії; загроза; система протидії; сектор безпеки і оборони.

Постановка проблеми. Затверджена Указом Президента України Концепція розвитку сектору безпеки і оборони України (СБОУ) [1] визначає необхідність сумісного використання військових і невійськових сил та засобів СБОУ.

Основною метою інтеграції військових і невійськових сил та засобів сектору безпеки i оборони України $є$ уникнення дублювання завдань, що покладаються на його окремих суб'єктів, та неекономного використання вкрай обмежених ресурсів, що виділяються в Україні для забезпечення іiї воєнної безпеки.

Це положення обумовлює необхідність розроблення рекомендацій щодо цілей, принципів, умов та можливих форм і способів (варіантів) інтеграції зусиль наявних у державі сил і засобів в інтересах нейтралізації загроз воєнного характеру. Рекомендації мають враховувати положення ст. 10 Закону України "Про основи національної безпеки України" [2], яким визначені основні функції суб'єктів забезпечення національної безпеки. Зазначене обумовлює актуальність даної публікації.

Аналіз останніх публікацій. Аналіз останніх досліджень та публікацій свідчить про те, що проблемам протидії та нейтралізації загроз воєнного характеру приділяється значна увага. Керівні документи 3 питань забезпечення національної та воєнної безпеки орієнтують суб' єкти сектору безпеки і оборони України на першочергове використання несилових структур та невійськових заходів для усунення або нейтралізації загроз воєнного характеру [1-3]. Багато наукових праць присвячені теоретико-методологічним основам забезпечення національної та воєнної безпеки [4], розробленню методів, моделей та методичних підходів i методик для обгрунтування практичних рекомендацій щодо зміцнення воєнної безпеки держави [5$11]$.

Водночас у вітчизняній науковометодичній літературі та зарубіжних наукових виданнях із проблематики забезпечення воєнної безпеки майже відсутні публікації, присвячені практичним рекомендаціям щодо інтеграції зусиль військових та невійськових суб'єктів сектору безпеки i оборони для нейтралізації загроз воєнного характеру.

Мета статті. Розроблення практичних рекомендацій щодо інтеграції зусиль військових і невійськових суб'єктів сектору безпеки і оборони України для нейтралізації загроз воєнного характеру.

Виклад основного матеріалу. Відомо, що ефективність спільного використання військових і невійськових сил та засобів під час нейтралізації загроз воєнного характеру залежить від можливостей окремих суб'єктів СБОУ, що залучаються до протидії, ефективності виконання суб'єктами поставлених ним завдань, ресурсного забезпечення інтеграції, як організаційного процесу та застосування визначених сил $\mathrm{i}$ засобів, як спільної діяльності, а також ефективності управління процесом нейтралізації загроз тощо $[4,9]$.

Викладені у праці [11] концептуальні погляди на створення системи протидії загрозам воєнного характеру та розроблений науково-методичний апарат [7-10] стали основою для розроблення рекомендацій щодо інтеграції зусиль військових і невійськових суб'єктів сектору безпеки i оборони для нейтралізації загроз воєнного характеру. До того ж в основу інтеграції зусиль суб'єктів СБОУ покладено формування інтегрованого 
потенціалу протидії загрозам воєнного характеру. Термін “загроза воєнного характеру" (3ВX) пропонується розуміти як такий, що ширше відображає розуміння суті таких загроз та їх безпосередній вплив на воєнну безпеку держави. Від інших загроз, які за своїми наслідками мають аналогічний ефект, що й застосування військових засобів, їх відрізняє цілеспрямований характер, а не якийсь випадковий збіг обставин.

Ураховуючи, що у праці [1] визначені шляхи формування національних безпекових та оборонних спроможностей для забезпечення протидії ЗВХ завдяки інтеграції зусиль СБОУ, але не зазначені умови та принципи їх сумісного використання важливими $\epsilon$ рекомендації щодо умов та порядку інтеграції військових і невійськових суб' єктів СБОУ.

Аналіз подій, що відбулися в Україні останніми роками свідчить про наявність цілеспрямованих, адаптивних до нашої держави загроз, що поєднують у собі як військові, так і невійськові дії (заходи), що набувають системного та комплексного характеру. Предметом цього впливу є не тільки суверенітет i територіальна цілісність України, а й психологічний тиск на населення та органи влади. Саме цілеспрямований характер і висока динаміка перетворення цих загроз із категорії потенційних до реальної їх реалізації потребують ретельного попереднього опрацьовування на державному рівні 3 розробленням відповідних комплексних заходів протидії.

Проведення комплексу заходів для адекватної протидії ЗВХ, що вже стали реальними потребує створення відповідного інтегрованого потенціалу, під яким розуміється найбільш доцільний склад сил i засобів суб'єктів СБОУ, що має спроможності для виконання визначених завдань (заходів) [11]. Реалізацію цих завдань (заходів) пропонується здійснювати за єдиним замислом, як правило, у формі спеціальної операції (кампанії) для нейтралізації виявлених (прогнозованих) 3ВХ у межах виділених державою та недержавними організаціями ресурсів.

Складність визначення мети, форм та способів інтеграції військових і невійськових суб'єктів СБОУ обумовлюється характером загроз і потребує застосування системного підходу, що обумовлює розгляд можливої сукупності військових і невійськових суб'єктів СБОУ для протидії ЗВХ як системи. В основу формування цієї системи, ii інтегративних якостей покладено цілеспрямованість системи як системоутворюючого фактора. Тобто визначена мета (цілі) такої системи $є$ об'єктивним критерієм вибору необхідного складу суб'єктів СБОУ та їх функцій щодо протидії загрозі, що виникла. Подальша декомпозиція та формалізація мети дадуть змогу надати їй коректного опису.

Для цього пропонується розгорнутіше формулювання мети інтеграції військових i невійськових сил та засобів, яке сприяє синтезу системи цих заходів, що була б у змозі ефективно протидіяти загрозам воєнного характеру. Тобто, пропонується створення відповідної системи протидії ЗВХ. Слід зазначити, що для кожної загрози має створюватися своя система протидії (нейтралізації).

Таким чином, 3 огляду на сутність загрози воєнного характеру, метою інтеграції зусиль військових і невійськових суб'єктів СБОУ є таке їх організаційне поєднання, яке при застосуванні за єдиного керівництва та відповідного планування були б здатні ефективно зменшити дію чинників, що формують загрозу, до прийнятних значень.

Ураховуючи характер загрози, відносно якої визначена загальна мета інтеграції зусиль суб'єктів СБОУ пропонується будувати систему цілей. Кількість цілей досягнення загальної мети та їх ієрархічних рівнів визначається обраною стратегією протидії (нейтралізаціï) загрозі, можливостями залучених до протидії суб'єктів СБОУ та їх структурних підрозділів за підпорядкуванням. Така сукупність цілей дасть змогу зв'язати воєдино довгострокові та короткострокові цілі й вибудувати загальну стратегію протидії ЗВХ. До того ж пропонується визначати такі види цілей:

стратегічні - для визначення протидії загрозам у довгостроковій перспективі;

тактичні - для вирішення окремих (специфічних) оперативних завдань суб'єктам CБOY;

траєкторні - визначають загальний напрям, у якому повинен змінюватися чинник або група чинників, що визначають загрозу.

У систему цілей (завдань) протидії ЗВХ у першу чергу доцільно включати завдання i відповідні їм заходи, що можуть бути гарантовано забезпечені ресурсами.

Основними системними вимогами до переліку цілей найнижчого рівня $є$ їх повнота, доцільність (ненадлишковість) та вимірність. Відомо, що вимірність цілей дає змогу визначати раціональний (доцільний) варіант інтеграції зусиль військових та невійськових суб' єктів СБОУ для нейтралізації ЗВХ [10]. 
Зважаючи на специфіку завдань, які можуть бути покладені на суб'єкти СБОУ щодо реагування на різні за характером ЗВХ слід очікувати, що на відміну від технічних та організаційних систем, у системі протидії загрозам, які пропонується створити на виконавчому рівні, вимірність цілей не завжди можна забезпечити за допомогою аналітичних розрахунків. Тому, відповідно до методики [10], пропонується використовувати підхід в основі якого $є$ формування цільової функції $F_{z}$, яка формально описує деескалацію рівня певної загрози (z) до прийнятного рівня. Опис процесу формування цільової функції зменшення рівня загрози ітераційним способом детально наведений у [10]. Необхідно зазначити, що сутність його полягає у зниженні показників “ваги” (пріоритету) певної загрози $(z)$ за рахунок комплексного використання військових та невійськових суб'єктів СБОУ для нейтралізації ЗВХ.

Важливим є положення, що вибір суб' єкта СБОУ доцільно визначати зважаючи на характер загрози, який визначається сферами у яких виявляється конфліктність. До того ж обрані для нейтралізації загрози суб'єкти СБОУ як військові, так і невійськові, повинні мати спроможності впливати на конфліктуючу державу у цих сферах так, щоб знижувалися показники загрози.

Отже, сукупність цілей (завдань) щодо нейтралізації ЗВХ має визначальний характер в організації процесу інтеграції зусиль військових і невійськових суб' єктів СБОУ з протидії ЗВХ.

Викладене дає змогу сформулювати як рекомендацію основні принципи, за якими доцільно здійснювати інтегрування зусиль військових і невійськових суб'єктів СБОУ для протидії загрозам воєнного характеру, а саме:

системності - закладений у мету протидії загрозам та передбачає отримання ефекту емерджентності від інтеграції військових i невійськових сил та засобів;

адекватності загрозі - висуває вимоги до відповідності залучених суб'єктів СБОУ, поставлених їм завдань та виділених ресурсів, чинникам, що формують загрозу. Забезпечується на основі використання розробленого методу адаптивного управління інтегрованим потенціалом протидії виявленій (прогнозованій) загрозі [8];

оптимізачиї розподілу зусиль між суб'єктами СБОУ та різного роду ресурсів, дотримання якого забезпечується використанням положень $[8,10]$;

науковості у формуванні інтегрованого потенціалу військових і невійськових засобів зобов'язує здійснювати всебічний аналіз загроз та забезпечувати обгрунтованість заходів із протидії на базі повної і достовірної інформації із застосуванням наукових методів і підходів [5-10] та відповідного програмного забезпечення;

принцип, що об'єднує принципи управлінської діяльності, які стосуються прийняття організаційно-управлінських рішень i забезпечують досягнення мети інтеграції зусиль суб'єктів СБОУ для нейтралізації 3ВX.

Наступною рекомендацією 3 інтеграції зусиль військових і невійськових суб'єктів СБОУ для нейтралізації ЗВХ пропонується вважати послідовність вироблення управлінського рішення на застосування окремих суб'єктів СБОУ в інтересах нейтралізації певної ЗВХ. Ця рекомендація розроблена на основі використання методики [10] та 3 урахуванням положень концепції [11].

Сутність цієї рекомендації полягає у визначеній послідовності підготовки обгрунтованих пропозицій особі (основних процедур), яка приймає управлінське рішення щодо інтеграції зусиль суб'єктів СБОУ для нейтралізації загрози військового характеру (рис. 1).

Процедури та розрахунки, що виконуються на етапах підготовки рішення щодо інтеграції зусиль військових та невійськових суб'єктів СБОУ для нейтралізації виявленої ЗВХ дають змогу адаптуватися до рівня і характеру виявленої (прогнозованої) загрози та гнучко використовувати наявні військові i невійськові можливості та ресурси для забезпечення воєнної безпеки України.

Запропонована послідовність підготовки управлінського рішення на інтеграцію зусиль окрім зазначеного дасть змогу отримувати потрібні спроможності для нейтралізації ЗВХ порівнюючи різні варіанти (комбінації) сил та засобів складових СБОУ на основі оцінки їх за такими показниками як тривалість проведення заходів нейтралізації загрози визначеним складом суб' єктів СБОУ, чисельності залучених до нейтралізації загрози сил та засобів. Важливим критерієм доцільності прийнятого рішення $\epsilon$ відповідність потрібних для нейтралізації ресурсів тим, що виділені або можуть бути виділені державою.

Критично важливим у запропонованій послідовності прийняття рішення на інтеграцію зусиль суб'єктів СБОУ $є$ 
моніторинг загроз. Адекватне та своєчасне оцінювання загроз обумовлюе необхідність мати певну модель загроз воєнній безпеці держави та модель системи моніторингу. Перша модель є базою даних, виявлених у різний час $\mathrm{i}$

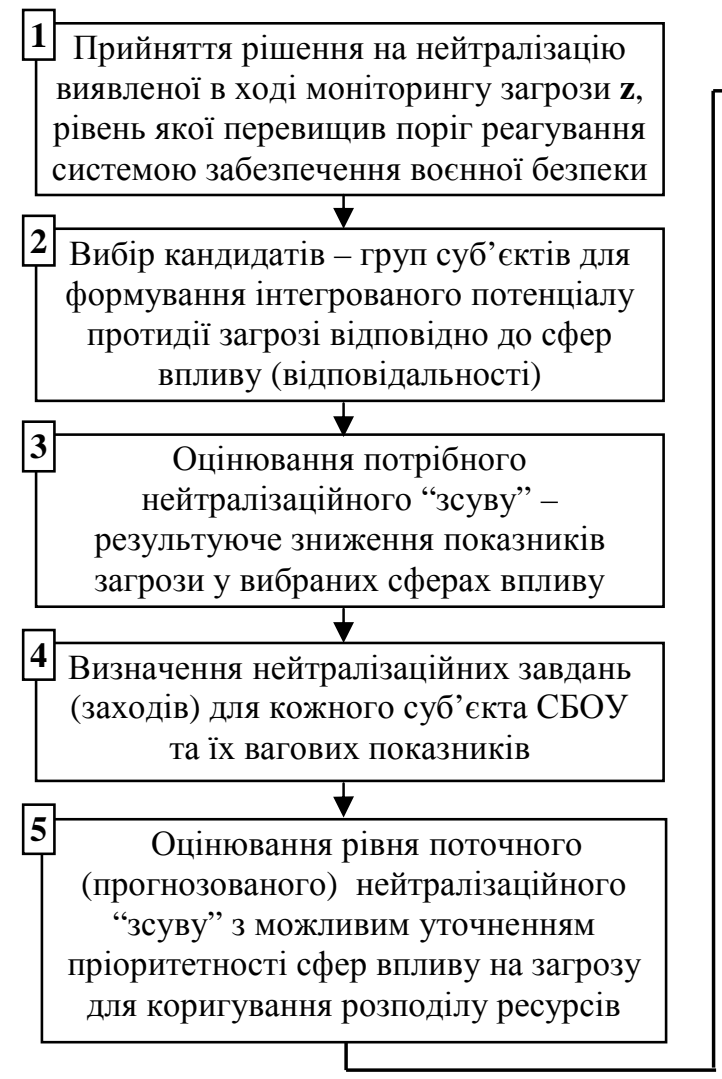

Рис. 1. Послідовність підготовки пропозицій до рішення щодо інтеграції зусиль суб'єктів СБОУ для нейтралізації виявленої загрози військового характеру

Об'єднання суб'єктів для забезпечення національної безпеки формально вже існує у вигляді СБОУ, інтеграція зусиль окремих суб'єктів (військових і невійськових) спрямовується у першу чергу на нейтралізацію ЗВX i раціональне використання ресурсів держави i можливостей складових СБОУ для отримання ефекту емерджентності від їх інтеграції, що складає сутність принципу системності.

Досвід залучення суб'єктів СБОУ до АТО, аналіз вимог щодо інтеграції зусиль військових та невійськових суб'єктів для нейтралізації ЗВХ обумовлюють підвищення управлінських можливостей керівництва держави. Це потребує створення системи стратегічного керівництва СБОУ нового формату відповідно до сучасних умов і потреб. Інтеграція зусиль військових і невійськових суб' єктів СБОУ на основі єдиного керівництва, 3 урахуванням даних [12], передбачає чіткий розподіл та делегування відповідальності під час формування, прийняття та реалізації рішень прогнозованих 3ВХ, кожна з яких описується характеристиками типового паспорта загроз, а інша описує нормативно визначену в державі процедуру виявлення загроз, на які СЗВБ має ефективно реагувати [4].
$6 \longdiv { 7 е р е в і р к а ~ н а ~ д о с т а т н і с т ь ~ п о т о ч н о г о ~ }$ (прогнозованого) нейтралізаційного “зсуву” з можливим корегуванням або визначенням нового варіанта нейтралізаційних завдань (заходів) (див. етап 4)

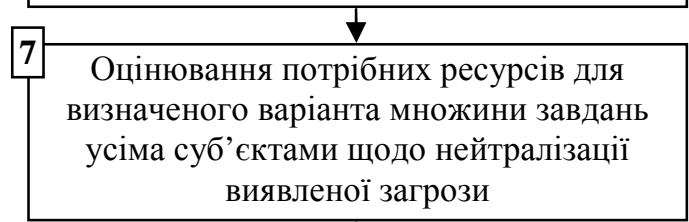
$\mathbf{\downarrow}$
Перевірка потрібних ресурсів на
відповідність виділеним для нейтралізації
загрози з можливим корегуванням у разі
невідповідності (див. етапи 2, 3, 4) $9 \sqrt{\text { Надання на затвердження проекту управ- }}$ лінського рішення щодо нейтралізації виявленої загрози визначеним складом суб'єктів СБОУ та обгрунтуванням завдань (заходів) кожному суб'єкту в усій системі управління - від воєннополітичного керівництва до окремих підрозділів суб'єктів, що залучаються до нейтралізації загроз. Варіант стратегічного керівництва СБОУ щодо інтеграції зусиль військових та невійськових суб'єктів для нейтралізації ЗВХ наведено на рис. 2.

Провідна роль у забезпеченні централізації управління СБОУ у мирний час, у кризових ситуаціях, які загрожують національній безпеці, та в особливий період, підвищенні рівня міжвідомчої координації і взаємодії надається Головному ситуаційному центру України (ГСЦУ). Важливою функцією системи стратегічного керівництва СБОУ $є$ раціональний розподіл завдань у СБОУ, формування системи управління силами безпеки і оборони залежно від типу кризової ситуації (загрози) та 3 урахуванням багатогранності ризиків національній безпеці.

Спільна, під єдиним керівництвом, діяльність суб' єктів СБОУ щодо нейтралізації загрози потребує визначення рекомендацій щодо форм i способів такої інтеграції. Розглядаючи можливі способи використання 
військових та невійськових суб’ єктів СБОУ, а конкретно наявних у них сил та засобів для протидії ЗВХ, пропонується взяти за аналогією розуміння способів ведення воєнних (бойових) дій - порядок та прийоми застосування сил та засобів задля вирішення завдань із протидії 3BX.

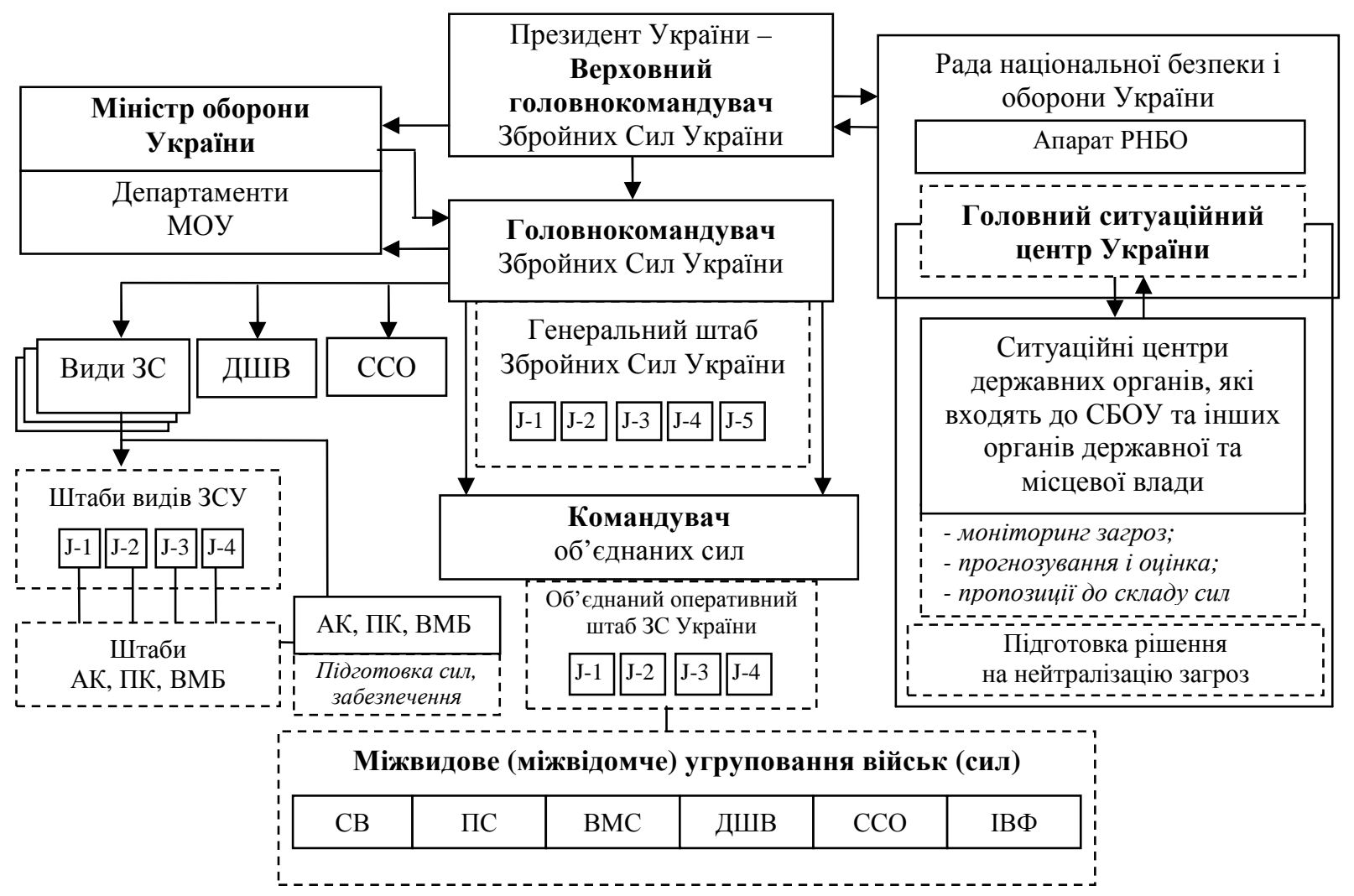

Рис. 2. Система стратегічного керівництва СБОУ щодо інтеграції зусиль військових і невійськових суб'сктів для нейтралізації ЗВХ (варіант)

Зазвичай, способам воєнних (бойових) дій притаманні основні складові (напрямок зосередження основних зусиль, послідовність розгрому противника, побудова військ, характер маневру тощо), зміст яких визначається бойовою обстановкою, характером дій противника та наявних сил та засобів. Відповідно і вибір способу інтеграції зусиль буде залежати від характеру конкретної загрози та своєчасності піi виявлення. Визначальними для вибору способів інтеграції зусиль пропонується вважати:

можливості сил та засобів, що залучатимуться до протидії в межах обраних суб'єктів СБОУ для формування інтегрованого потенціалу протидії загрозі відповідно до сфер впливу;

якісні характеристики кадрів, на які покладатимуться розроблення загальної стратегії протидії загрозі та розроблення i виконання завдань (заходів) на рівні суб'єктів СБОУ.

3 урахуванням наведеного пропонуються основні способи інтеграції зусиль військових і невійськових засобів суб'єктів СБОУ для нейтралізації ЗВХ, а саме: інтеграція військових і невійськових сил та засобів із наданням пріоритету несиловим засобам із застосуванням силових для підтримки.

Зрозуміло, що кожен із зазначених способів інтеграції може мати безліч варіантів конкретного переліку застосованих тих або інших як сил і засобів, так і суб' єктів СБОУ та ступеня їх участі у ході реалізації головної мети (стратегії нейтралізації загрози) їх інтеграції.

Рекомендації щодо форм інтеграції зусиль суб'єктів СБОУ щодо нейтралізації загроз полягають в уточненні та конкретизації термінів “операція" та “кампанія", що пропонуються для використання. Форма інтеграції зусиль суб'єктів СБОУ визначатиметься обраним способом нейтралізації загроз, який залежить безпосередньо від характеристик самої загрози (або кількох загроз) для нейтралізації якої проводиться інтеграція суб' єктів СБОУ. Термін “операція", що пропонується як основна форма нейтралізації загрози, за суттю відповідає визначенню терміну операція, що використовується у воєнному мистецтві і може бути сформульована як “сукупність узгоджених 
та взаємозв'язаних за метою, завданнями, місцем і часом дій та заходів сил та засобів визначених військових i невійськових суб' єктів СБОУ, що проводяться відповідно до обраної стратегії нейтралізації загрози".

Особливості загроз, як об'єкта дослідження, та складність їх нейтралізації дають підстави на використання такої форми інтеграції зусиль, як “кампанія”, хоча цей термін у воєнному мистецтві практично не вживається. Однак, як зазначалось вище, загроза (загрози) формується багатьма чинниками, дія яких характеризується: масштабністю; як правило, значними часовими межами; спрямованістю на різні державні інституції та суб'єкти, що впливають на стан обороноздатності держави тощо. Відповідно й адекватна реакція на загрозу (загрози), яку необхідно нейтралізувати спільними зусиллями потребує значних часових витрат, залучення до протидії різних суб'єктів СБОУ (i не тільки), фінансових та матеріальних ресурсів і виходить за рамки “операціі”, яка має більш конкретний, окреслений у часі та завданнях характер. Тобто “кампанія" стає формою досягнення стратегічної мети нейтралізації найбільш небезпечної (масштабної) загрози державного рівня або кількох загроз, що виникли одночасно. У цьому випадку “операція", як основна форма інтеграції, застосовуватиметься для досягнення окремих оперативних цілей "кампаніï" 3 нейтралізації 3ВX. Отже інтеграція зусиль різних суб'єктів СБОУ для нейтралізації ЗВX у формі “кампаніi”" полягатиме у проведенні кількох одночасних або послідовних операцій, які підпорядковані обраній стратегії нейтралізації загрози.

3 огляду на наведені рекомендації щодо формулювання мети, принципів, порядку прийняття управлінського рішення на інтеграцію, а також способів та форм інтеграції зусиль військових та невійськових суб'єктів СБОУ для нейтралізації ЗВХ важливим є розуміння, що термін “інтеграція" розглядається 3 кількох позицій: “інтеграція" як цілеспрямоване об'єднання окремих (військових і невійськових) суб'єктів СБОУ для спільної діяльності 3 нейтралізації загроз (суто організаційне завдання); “інтеграція" як спільна діяльність окремих (військових i невійськових) суб'єктів СБОУ, що здійснюється відповідно до визначеної стратегії нейтралізації загрози.

Важливою рекомендацією щодо інтеграції зусиль військових i невійськових суб'єктів СБОУ для нейтралізації ЗВХ, є удосконалення стратегічних комунікацій в системі забезпечення воєнної безпеки держави. Нині стратегічні комунікації у військовій сфері це передусім діяльність, яка спрямована на гармонізацію всіх заходів у сфері публічної дипломатії, зв'язків із громадськістю та військових (інформаційних) операцій. Вони спрямовані на підрив та делегітимізацію противника шляхом набуття підтримки й визнання 3 боку місцевого населення, електорату своєї країни, міжнародних організацій та громадськості [13]. В умовах проведення “Операції об’єднаних сил” на Сході України це має пріоритетне значення для відновлення миру.

3 досвіду НАТО, стратегічні комунікації дають змогу спрямувати за одним вектором множину різних видів діяльності та підпорядкованим їм заходів для забезпечення національної безпеки. Це підтверджує важливість стратегічних комунікацій у питанні нейтралізації загроз воєнного характеру, особливо 3 огляду на вимоги керівних документів з питань забезпечення національної та воєнної безпеки щодо пріоритетності невійськових заходів. Як приклад, труднощі, що виникли під час “Операції 3 підтримання безпеки в Афганістані” зумовили рішення Верховного головнокомандувача ОЗС НАТО в Європі про те, що діяльність у сфері стратегічних комунікацій має бути включена до переліку завдань Штабу Верховного головнокомандувача. Ініціативу перейняла i політична штаб-квартира в Брюсселі, де відділ громадської дипломатії долучив стратегічні комунікації до своїх основних завдань [13].

\section{Висновки}

\section{1. Урахування}

запропонованих рекомендацій у практичній діяльності СБОУ дає змогу здійснювати інтеграцію зусиль військових і невійськових суб'єктів СБОУ в умовах ресурсних обмежень під єдиним управлінням та адаптуватися до рівня та характеру загроз.

2. Послідовність

вироблення

управлінських рішень щодо інтеграції зусиль військових та невійськових суб' єктів СБОУ для нейтралізації загроз воєнного характеру, розроблена на основі використання методу адаптивного управління інтегрованим потенціалом протидії виявленій (прогнозованій) загрозі, визначає по суті спосіб розподілу завдань (заходів) між військовими i невійськовими суб' єктами та відповідальність за їх виконання без деталізації на рівні окремих 
суб'єктів СБОУ.

3. Підготовлене управлінське рішення щодо інтеграції зусиль військових та невійськових суб' єктів СБОУ для нейтралізації загроз воєнного характеру дає змогу впорядкувати функції СБОУ та поліпшити управління і цивільний контроль, перейти до централізованого всебічного забезпечення процесу реалізації національних інтересів у воєнній сфері.

4. Наведені рекомендації щодо формулювання мети, принципів, порядку прийняття управлінського рішення на інтеграцію, а також способів та форм інтеграції зусиль військових і невійськових суб'єктів СБОУ для нейтралізації ЗВХ можна вважати подальшим розвитком методології забезпечення воєнної безпеки держави.

Подальші дослідження доцільно зосередити на розробленні рекомендацій щодо уточнення заходів (завдань) військовим i невійськовим суб'єктам сектору безпеки i оборони України та удосконаленні технологій моніторингу загроз воєнного та гібридного характеру 3 боку тих держав, які розглядаються як потенційно небезпечні 3 воєнної точки зору.

\section{СПИСОК ВИКОРИСТАНОЇ ЛІТЕРАТУРИ}

1. Концепція розвитку сектору безпеки і оборони України [Текст] : схвалена Указом Президента України [від 14.03.2016 № 92/2016]. - К.: АПУ, 2016. $-17 \mathrm{c}$.

2. Про основи національної безпеки [Текст] : Закон України від 19.06.2003 № 964-IV (із змінами, внесеними згідно із Законом від 12.02.2015 № 186-VIII) // Законодавство України з питань військової сфери. - К.: Урядовий кур'єр від 19.08.2015 № 15 .

3. Стратегія національної безпеки України: Указ Президента України: від 26.05.2015 № 287. - К.: АПУ, 2015. - $12 \mathrm{c}$.

4. Богданович В. Ю. Теоретико-методологічні основи забезпечення національної безпеки України [Текст] : моногр. : у 7 т. - Т. 4. - Воєнна безпека держави i шляхи ii забезпечення / В. Ю. Богданович, І. Ю. Свида, Є. Д. Скулиш; за заг. ред. Є. Д. Скулиша. - К.: Наук.-вид. відділ НА СБ України, 2012. - 464 с.

5. Романченко І. С. Метод обгрунтування завдань щодо безпекового супроводу реалізації національних інтересів у системі забезпечення національної безпеки [Текст] / I. С. Романченко, В. Ю. Богданович, І. Ю. Свида // Зб. наук. праць ЦНДІ ЗС України. - К., 2011. - № 1 (55). - С. 5-18.

6. Богданович В. Ю. Комплексна модель управління інтегрованим потенціалом протидії загрозам воєнного характеру для забезпечення визначеного рівня воєнної безпеки держави / В. Ю. Богданович, О. В. Павловський // Наука і техніка Повітряних Сил Збройних Сил України. - 2017. - № 1 (26). С. 6-11.

7. Сиротенко А. М. Когнітивний підхід до визначення завдань складовим інтегрованого потенціалу деескалації загроз воєнного характеру в системі забезпечення воєнної безпеки / В. Ю. Богданович, І. Ю. Свида // Наука і техніка Повітряних Сил Збройних Сил України. - 2018. № 3. - С. 12-18.

8. Сиротенко А. М. Метод адаптивного управління інтегрованим потенціалом протидії виявленій (прогнозованій) загрозі / А. М. Сиротенко, В. Ю. Богданович, І. Ю. Свида // Наука і техніка Повітряних Сил Збройних Сил України. - 2017. № 4 (29). - С. 5-10.

9. Богданович В. Ю. Методичний підхід до визначення необхідних спроможностей складових інтегрованого потенціалу протидії загрозам на виконавчому рівні / А. М. Сиротенко, В. Ю. Богданович, А. М. Прима. - Харків: ХНУПС, Наука і техніка Повітряних Сил ЗС України, - 2017 - № 2 (27). С. 162-166.

10. Сиротенко А. М., Методика проектування необхідних спроможностей складових інтегрованого потенціалу деескалації загроз на виконавчому рівні / А. М. Сиротенко, В. Ю. Богданович, І. Ю. Свида // 3б. наук. праць ЦНДІ ЗС України. - К., 2017. - № 3 (81). C. $48-56$.

11. Сиротенко А. М. Концепція комплексного використання військових та невійськових сил і засобів для забезпечення достатнього рівня воєнної безпеки держави /А. М. Сиротенко, В. Ю. Богданович, І. Ю. Свида // Наука і техніка Повітряних Сил Збройних Сил України. - 2018. № 2 (31). - С. 16-29.

12. Фролов В. С. Протиборство агресії / В. С. Фролов, Ф.В. Саганюк // Оборонний вісник К., Центр воєнної політики та політики безпеки, 2017. - № 11. - C. 147-152.

13. Баровська А. В. Стратегічні комунікації: досвід НАТО [Текст] / А. В. Баровська, // Стратегічні приорітети. - К., НІСД, 2015. - № 1 (34). C. $147-152$. 


\section{Сиротенко А. Н., к.Т.н.}

Национальный университет обороны Украины имени Ивана Черняховского, Киев

\section{Рекомендации по интеграции усилий военных и невоенных субъектов сектора безопасности и обороны для нейтрализации угроз военного характера}

Резюме. В статье приведены рекомендации по комплексному использованию военных (силовых) и невоенных (несиловых) субъектов сектора безопасности и обороны Украины для противодействия угрозам военного характера. Рекомендации разработаны с учетом основных принципов, согласно которым должна происходить интеграция военных и невоенных субъектов для нейтрализации угроз военного характера и метода адаптивного управления интегрированным потенциалом противодействия выявленным (прогнозированным) угрозам.

Ключевые слова: военная безопасность; военные и невоенные субъекты; интегрированный потенциал противодействия; система противодействия; сектор безопасности и обороны; угроза.

\section{A. Sirotenko, PhD (Technical)}

The National Defence University of Ukraine named after Ivan Cherniakhovskyi, Kyiv

Recommendations for integrating the efforts of military and non-military actors in the security and defense sector to neutralize military threats

Resume. The article provides recommendations on the integrated use of military (security) and non-military (non-military) actors in the security and defense sector of Ukraine to counter the threats of a military nature. The recommendations are developed taking into account the main principles according to which the integration of military and non-military actors should take place in order to neutralize military threats and the method of adaptive management of the integrated potential to counter identified (predicted) threats.

Keywords: military security; military and non-military subjects; integrated counteraction potential; counteraction system; security and defense sector; threat. 